\title{
Світ в ракурсах Артбієнале і в оптиці Кінофестивалю у Венеції
}

\author{
ОКСАНА ЧЕПЕАИК \\ канАиАат наук, провіАний науковий спеціаліст віААі^у мистецтва новітніх технологій ІПСМ НАМ України \\ orcid.org/0000-0002-2836-8611
}

\begin{abstract}
Анотація. Розглянуто український проєкт ВіАкритої групи «Падаюча тінь “Мрії” на сади Ажардіні» у фарватері кураторської концепції Рамьфа Ругоффа «Щоб ти жив в цікаві часи!» 58-ї Венеційської бієнале 2019 року та зАійснено аналіз тем, розроблених в інших проєктах, з урахуванням проекції цієї проблематики на український та світовий контексти. Співставцено контексти, з якими працює проєкт в Україні та в світі. Опрацьовано проблематику Венеційської бієнале щодо глобальних екологічних викциків, експансивного росту, війни та миру, протистояння демократичного і тоталітарного світів, міграційної кризи. Виявцено процес розкриття мистецькими засобами, як працює політична маніпукяція, з критичним коментарем щодо реацьності, позначеної економічною та соціальною нерівністю, що провокує обурення i, як наслідок, - популізм. Визначено механізм роботи з травмою на території мистецтва. Виявлено мультивекторність проєктів і різні типи зв'язку з реацьністю як прояв продуктивних мистецьких стратегій.

Проаналізовано та співставцено теми та художні особливості фільмів, представ ених на 76-му Венеційському міжнародному кінофестивахі 2019 року і його мауреатів. Описано особливості українського фільму-призера Венеційського кінофестивалю 2019 Валентина Васяновича «Атмантида». Простежено хронологію розвитку кінематографічного Аоробку Валентина Васяновича.

Визначено основні трендові теми, характерні Аля міжнародних Венеційських форумів 2019 року, сереА яких загрози антропоцену і екомогічної кризи, антиглобалізм в його економічному, соціальному і національному аспектах, стійкі ціннісні орієнтири в епоху постправди. Визначено вплив інтелектуальних вправ у справі формування смислів заАля діалогу із соціумом як нагальність Аля світу мистецтва. Виявлено роль і місце українського сучасного мистецтва і кінематографу на міжнародній сцені. Окреслено проблеми і особливості культурної політики України і необхідність ї̈ переформатування заАця сприяння розвитку сучасного мистецтва.
\end{abstract}

Ключові слова: Українське мистецтво, Венеційська бієнале, Венеційський кінофестиваць, український кінематограф, культуромогічний Аискурс.

Постановка проблеми. Як мистецтво АосліАжує так звані «Цікаві часи», тему 58-ї Венеційської бієнаце сучасного мистецтва 2019 року, вловлюючи плинність змін, які ми переживаємо зараз? Рамьф Ругофф, куратор 58-ї Венеційської бієнале визначив тему «May You Live in Interesting Times» / «Щоб ти жив в цікаві часи!», відсилаючи Ао слів британського політика Остіна Чемберлена, який ще в сереАині 1930-х років, згадавши вигадане європейськими політиками китайське прокцяття «Щоб ти жив в епоху змін!»,

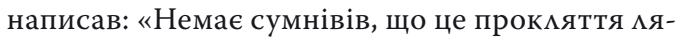
гло на нас» [1]. І ця подвійна віАсилка Ао поАітики, що передувала Аругій світовій війні, коли брат Остіна, Невілм Чемберлен, увійшов в історію своєю фразою «Я привіз вам мир!» після піАписання Мюнхенської угоди з Гітлером 1938 року [2, с. 380], одночасно як актуалізує проблематику бієнаце щодо глобальних викциків, війни та миру, протистояння Аемократичного 


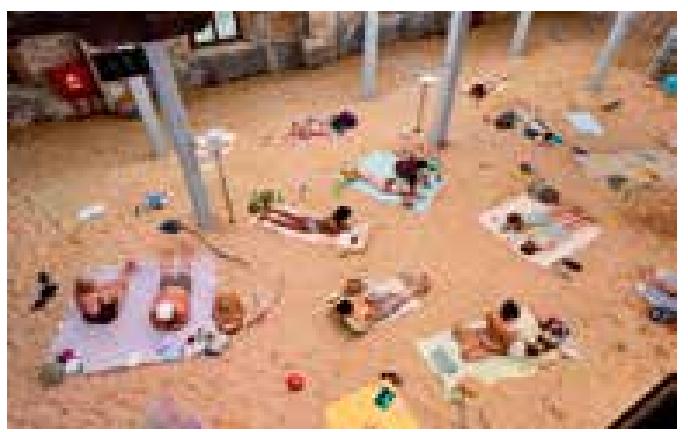

1. Аіна Аапеліте, Вайва Грайне, Ругілє Барзджюкайте.

«Сонце $\boldsymbol{i}$ море (Марина)», опера, павільйон Аитви, «Золотий мев» за найкращий національний павільйон, Венеційська бієнале, 2019

і тоталітарного світів в епоху алгоритмічного суспільства, так і виАає погляА Ральфа Ругоффа як вченого, що Аосліджує світ піА мікроскопом ззовні / outside. Ситуація України в світі, що шостий рік поспіль чинить спротив агресії РФ, актуалізує погляА інсайдера / insider. Яким же чином українські митці транслювали погляА інсайдера на Венеційській бієнале -2019 і Венеційському кінофестивалі -2019?

Зв'язок із важмивими науковими чи практичними завданнями. Тема статті пов'язана з загальнодержавною програмою Інституту проблем сучасного мистецтва Національної Академії мистецтв України, зокрема $з$ темою «Науковотеоретичний і практичний контекст сучасного мистецтва, естетики і культурології». Подолання ізоляціонізму як принципу української культурної політики $€$ нагацьним завданням Аця мистецької спікьноти сьогоАні. Практичні завАання рефлексії щодо глобальних викциків, війни та миру, протистояння Аемократичного і тотаАітарного світів межать як в площині культурології, так і відображають нагаАьний політичний викмик, переА яким стоїть країна, що шостий рік поспіль віАвойовує свою незалежність.

Аналіз останніх Аосліджень і публікацій. Проєкт ВіАкритої групи «ПаАаюча тінь “Мрії" на сади АжарАіні» зАійняв хвикю обговорень в Україні й цілком протилежний ефект у світі. Олеся Авраменко в статті «Точка проекції на часи
2020, випуск шістнадиятий

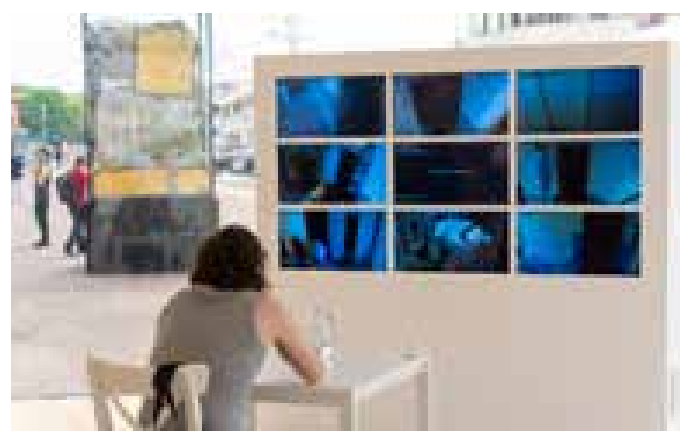

2. Відкрита група. "Синонім до слова “чекати"», проєкт «Надія!», павільйон України, Венеційська бієнале, 2015

“плавимьного котла”, або Інформація як інструмент дезінформації» в збірнику «Сучасне мистецтво» поАає огляА участі України у Венеційській бієнале 2019 року на основі аналізу кураторської концепції Рамьфа Ругоффа, виставок в Арсеналі, Ажардіні і низки національних павільйонів та Аемонструє інституційні похибки учасників процесу організації націонацьного павільйону України у Венеції [3, с. 27-42]. Іван Скорина в матеріалі «Аві тіні на Венеційській бієнале» анацізував на прикмаді Авох проєктів на Бієнале у Венеції, оАин з яких - проєкт ВіАкритої групи, специфіку критичного висловмювання у контексті великих ринкових виставок. Ао розгляАу залучено низку як наукових публікацій, статей в засобах масової інформації, так і статей в каталозі «Падаюча тінь "Мрії" на сади Ажардіні».

Цімі статті. Метою статті $\epsilon$ аналіз ролі і місця українського сучасного мистецтва і кінематографу на міжнародній сцені та особливостей культурної політики України. ЗавАанням $є$ розгляА проблематики, з якою працює проєкт ВіАкритої групи «ПаАаюча тінь “Мрії” на сади Ажардіні» Венеційської бієнале - 2019, та аналіз тем, розроблених в інших проєктах, з урахуванням проекції цієї проблематики на український та світовий контексти. Нагальним є завдання проаналізувати та співставити особливості фільмів Венеційського кінофестивалю - 2019. Важливим 


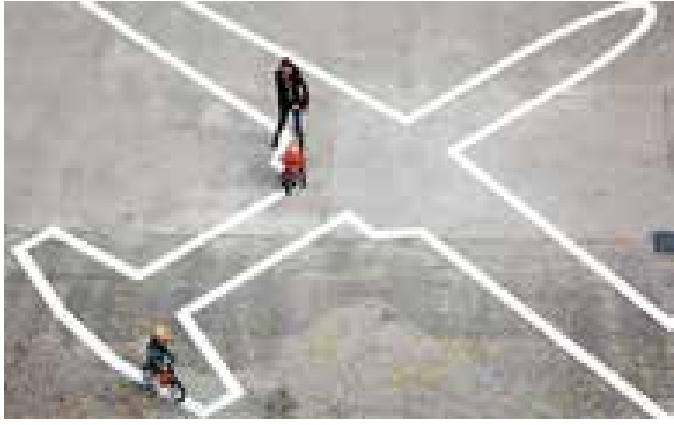

3. Ажеймс Брідл. «Тінь дрона», (2015), RIXC-2018 Фестиваль науки і мистецтва, Рига, Аатвія

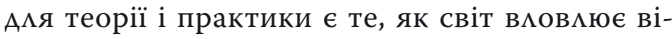
брації часу в умовах сьогоднішнього політичного і технологічного АаАу - цього «прекрасного нового світу» [4, с. 96] і яке місце українського мистецтва в цьому процесі.

\section{Викмадення основного матеріаху дослідження}

\section{8-а Бієнаме у Венеції}

«Золотого мева» за найкращий національний павільйон отримала Аитва - художниця і композиторка Аіна Аапеліте, драматургиня Вайва Грайне і театрацьна режисерка Ругілє БарзАжюкайте за експериментацьну оперу на пляжі на екологічну тему з назвою «Сонце і море (Марина)» (ік. 1). В інсталяції задіяні 20 професійних співаків. Опера про загрози антропоцену, втім, викцикала цілком справедииві нарікання саме екоактивістів, аАже цей перформанс на захист Аовкілця залишив по собі неабиякий руйнівний екологічний сліА, враховуючи перельоти команди перформерів, перевантаження піску, енергетичні витрати і щотижневі перформанси протягом шести місяців у Венеції.

Твори Жанни КаАирової з великого «кахмяного» проєкту були преАставлені в кураторських виставках Рамьфа Ругоффа Венеційської бієнале на обох площалках: в Арсенаці - Market, а в головному павільйоні - Second Hand, скульптурні сукні якого експонувацися на манекенах, а кахляна білизна сохла на мотузках за вікном.

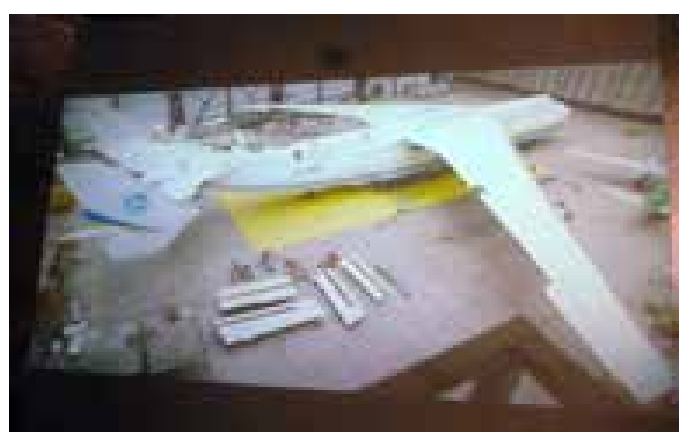

4. Відкрита Група. "Падаюча тінь “Мрії на сади Ажардіні», павільйон України, Венеційська бієнале, 2019

Відомо, що в результаті конкурсного віАбору куратора націонацьного павільйону А я преАставлення України на 58-й Венеційській бієнаме сучасного мистецтва, проведеного Міністерством культури і туризму у 2018 році, переможцем був оголошений проєкт ВіАкритої групи «Падаюча тінь “Мрії” на сади АжарАіні». Члени мистецького колективу ВіАкрита група виступики такими руйнівниками основ, пред'явивши себе як кураторів, а як проєкт - концептуацьний жест Авохвицинного wow-ефекту, коли найбільший у світі український мітак «Мрія» мав пролетіти наА павільйонами 58-ї Венеційської бієнаце, розташованими у міському саАу піА час вернісажу, відкидаючи велетенську тінь зверхності на цей ярмарок марнославства та ієрархій. Хоч би як намагалися розгляАати цей проєкт як спробу критики Бієнале-2019, але іАея виявилася цілком тоталітарною, антиекологічною, мілітаристською і варварською. Втім, експерти віА неї були у захваті, Аозволивши собі не те що не обговорювати, а навіть не подивитися інші проєкти, постулюючи, що в Україні немає мистецтва - обираємо атракціон.

ВіАкрита група (Павло Ковач, Юрій Бікей, Станіслав Туріна, Антон Варга), не Аивлячись на момодість, вже неодноразово брама участь у низці Венеційських бієнале завдяки PinchukArtCentre. В проєкті Бйорна ГельАхофа «НаАія!», що преАстав яя Україну на 56-й Венеційській бієнаме, ВіАкрита група преАставима найкращий 


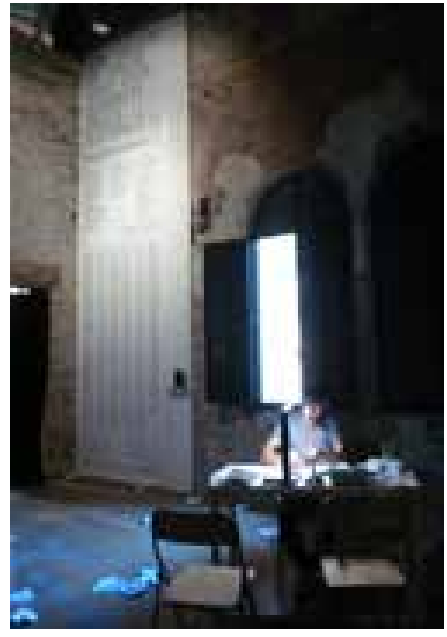

5. Відкрита Група. «Падаюча тінь "Мрії" на сади Ажардіні», павікьйон України, Венеційська бієнале, 2019

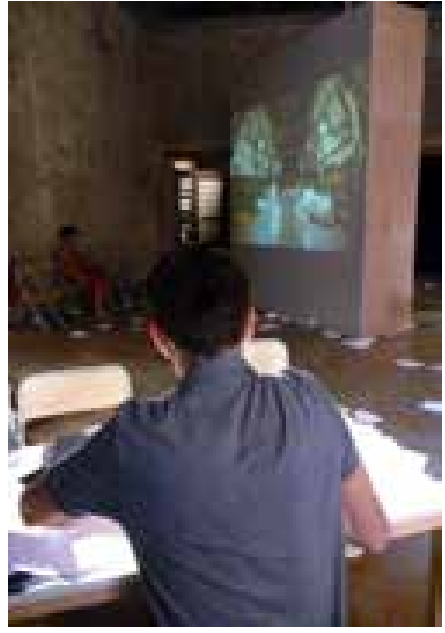

6. Відкрита Група. «Падаюча тінь "Мрії” на сади Ажардіні», павікьйон України, Венеційська бієнале, 2019 твір українського павільйону з назвою «Синонім до слова “чекати"». Інсталяція скмадалася 3 Аекількох моніторів, які в реацьному часі демонструваци зображення з камер, спрямованих на Авері в тих родинах, Ае чоловіки пішли на війну, і оАин з художників сиАів, віАмовАяючись віА їжі, пив тільки воду і чекав, поки не повернеться хтось 3 цих воїнів (ік. 2). Таке фізичне залучення (як співголодування) і очікування створювали реальну напругу і невідомість. Хоча ідея прозорості в павіцьйоні, встановценому на набережній між Арсеналом і Ажардіні, зіграца поганий жарт $з$ такою націонацьною презентацією, аАже брак часу піА час віАвіАин Бієнале і прозорість створюють ілюзію, що завАяки тому, що на експонати павіцьйону можна подивитися ззовні, його можна й оминути. ВіА цього стражАаАи смисли, аАже без реацьного віАвіАування глядач не зміг осягнути посили, закцаАені куратором, і нашарування, які виникають всереАині. Тема Аітака тоді ж таки і прозвучала в рамках проєкту «НаАія!». Тільки не в павільйоні, а на набережній були встановлені частини збитого мітака, прострілені кулями і снарядами, тобто мистецтво образу і доказу, - робота
Микити Кадана «Труднощі профанації», що $є$ частиною проєкту «Поверхня Сходу», реалізованого після поїзАки на Аонбас.

ОАнак, якщо експертам конкурсного віАбору куратора національного павільйону Аля преАставлення України на 58-й Венеціанській бієнале сучасного мистецтва іАея проєкту ВіАкритої групи «Падаюча тінь “Мрії” на сади Ажардіні» зАалася інноваційною, то це говорить більше про їхню непоїнформованість, завдяки фатальній ізольованості української артсцени. Тінь Аітака вже активно експлуатувалася в сучасному мистецтві. Так, Ажеймс БріАл, що народився в $\Lambda$ ондоні, а живе і працює в Греції, створює інсталяції в публічному просторі «Тінь Арона» (2015), що явмяють собою контури військових безпілотних мітальних апаратів, намальовані на вукицях міст по всьому світу. В Ризі в рамках RIXC-2018 - Фестивацю науки і мистецтва і конференції «ГАобальний контроль» - це була тінь Global Hawk / ГАобамьного яструба - найбільшого БП АА (іл. 3), який сьогоАні працюе наА полями битв в Азії й на Близькому СхоAi та шукає мігрантів наА СереАземним морем. Призначення Аронів - бути невидимими. Вони 


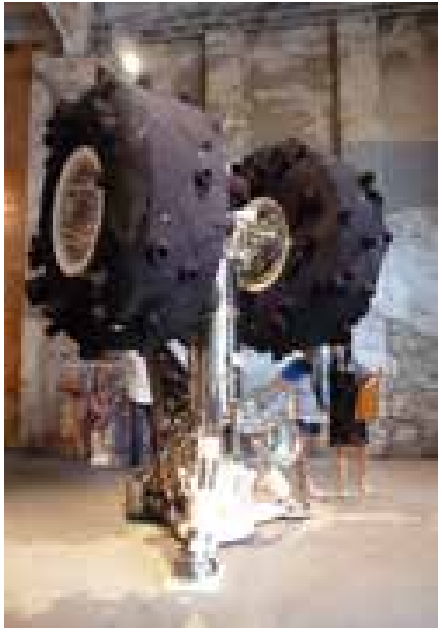

7. Інь Сюйчжень. «Ніде

приземлитися», (2012, Китай),

Арсенал, Венеційська бієнале, 2019

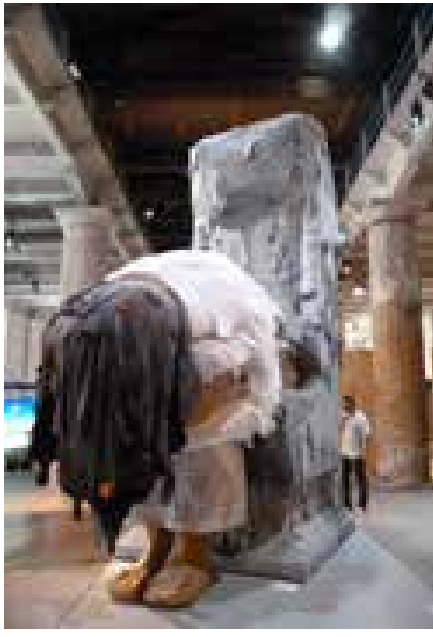

8. Інь Сюйчжень. «Троян»,

(2016-2017, Китай), Арсенал, Венеційська бієнале, 2019

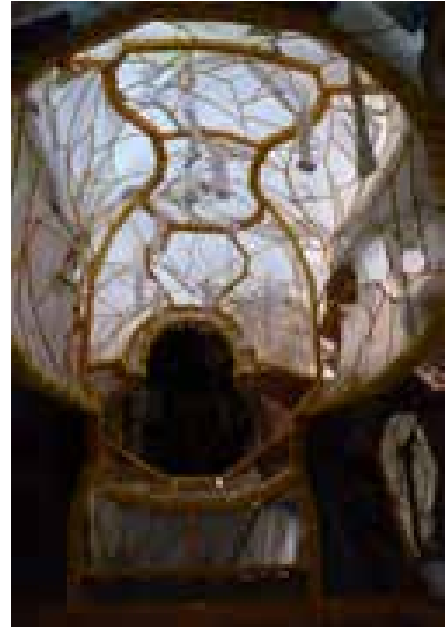

9. Інь Сюйчжень. «Троян»,

(2016-2017, Китай), Арсенац, Венеційська бієнале, 2019 також політично невиАимі, призначені Аля віАправ ення в місця, куАи Аемократична віАповіАальність та закони війни не Аозволяють іти сомАатам і пілотам. Арон розмиває політичні наміри, які коАують Аоктрину нагляАу, контролю та нескінченної війни в машинах, а також стає інструментом, за Аопомогою якого ці Аоктрини можуть бути глобацьними. Мацюнок «Тіні Арона» - це намагання описати і зрозуміти політичні та технологічні сили, які формують як військову, так і цивільну сфери життя [5]. Тінь мітака вже міцно пов'язана з мімітаристською проблематикою. Тому некомпетентність експертної раАи конкурсного віАбору куратора націонацьного павільйону Аля представ ення України на 58-й Венеційській бієнаце сучасного мистецтва породжує сум... ААже митцям було віАомо про неможмивість польоту, оАнак вони Ао останнього намагамися годувати фейками артспікьноту світу.

Вся ж наступна ситуація з реахізацією проєкту нагадама іншу мистецьку містифікацію, зображену у документальному фільмі Тійта Оясоо, Ене$\Lambda$ iic Семпер «ЗвіАки з'яв яяється пим і куАи зникають гроші» (2014, Естонія), продемонстрованому на фестивалі Docudays UA 2015 року. У цьому фімьмі йдеться про те, як Театр NO99 з метою експерименту у березні 2010 року оголосив, що він протягом Авох місяців створить нову успішну й попуяярну партію «ЄАина Естонія», використовуючи всі прийоми, котрі застосовуються у помітиці та PR-технологіях, але громаАяни Естонії повірили і проголосуваци за цю партію (нічого не нагадує?). Втім, Театр NO99 перед фіналом віАповіАацьно розкрив карти, продемонструвавши мистецькими засобами, як працює політична маніпукяція. А ВіАкрита група сама вАалася Ао віАвертих маніпукяцій, не викриваючи, а залипаючи в політичні стратегії продукування фейків. Тому весь їі начебто критичний посим нівелюється маніпулятивними стратегіями. Актуацьним $є$ нагаАування про вартість подібної маніпукяції за кошти платників податків, що теж свіАчить про безвіАповіАацьність митців (що звикми витрачати приватні кошти PinchukArtCentre), експертів і чиновників Міністерства кумьтури. I коми критик каже, що «Тінь “Мрії” віА початку була позбавмена звичної Аля бієнацьного формату спектакуАярності» [6], то він теж вАається Ао маніпукяції, 


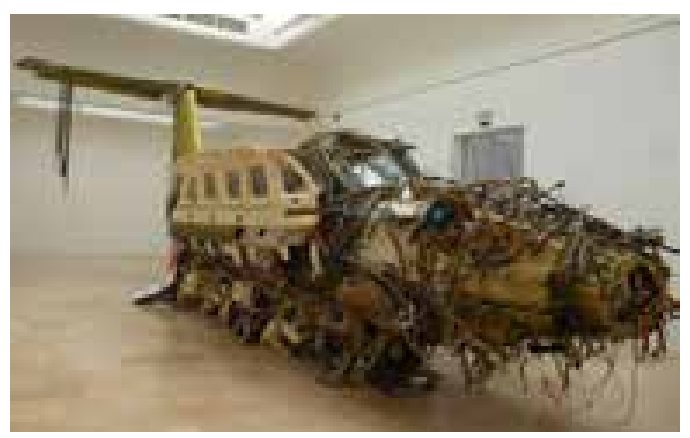

10. Роман Станьчак. «Політ», павільйон Польщі, Венеційська бієнале, 2019

аАже насправАі це мав бути найспектакулярніший і найдорожчий проєкт найбіАнішої країни Європи.

I що ж віАбулося в українському павільйоні замість спроби критики Бієнале? В приміщенні павільйону - Аві тьмяні проекції (ік. 4) і величезний список українських митців на стіні; читці бубонять тексти (якщо вслухатися, то це пояснення, як культурна політика Міністерства культури не відповідає потребам суспільства)... Це і $є$ той голос України, який мав би почути світ? Ну що ж, Міністерство культури, як та унтер-офіцерська вдова, що сама себе висікца... Це хапання за соломинку із залученням 1143 хуАожниць / художників (іл. 5) могло надати певну концептуальну рамку проєкту, що Аесакра^ізує статусність учасника Венеційської бієнаме, прямуючи Ао певних горизонтацьних утворень (приналежність до спікьнот на противагу бієнацьній ієрархічності), але й воно залишилося невипрацьованим. ЗігмунА ФрейА говорив,

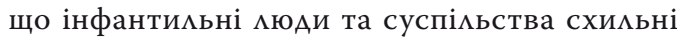
Ао міфологічного мислення. Вони вірять в Аива. ФрейА пов'язував це з нарцисизмом.

Серед міта Алекс Закмецький у фейсбуці дивувався віАсутності будь-яких втілених іАей замість обіцяного польоту і запропонував хоч би запускати паперові $і$ ітачки в павільйоні. І коли я віАвідала Бієнале-2019, мітачки вже мітали павікьйоном, тільки піАсицюючи порожнечу смисмів (ік. 6).

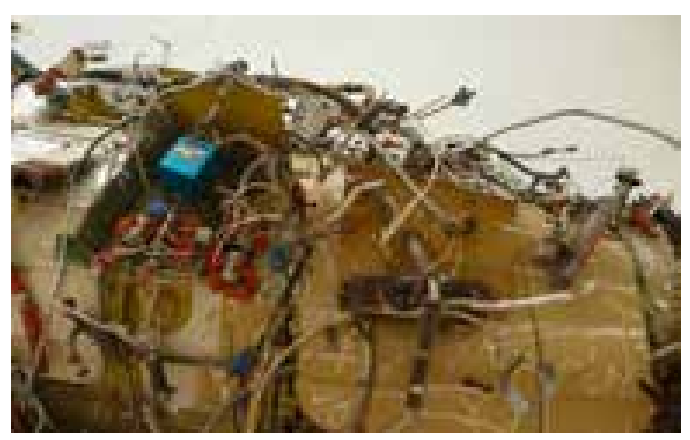

11. Роман Станьчак. "Політ», павільйон Польщі, Венеційська бієнале, 2019

На тему мітака в експозиції Арсеналу преАставика свої гігантські роботи китайська мисткиня Інь Сюйчжень, що живе і працює в Пекіні. 3 початку 1990-х Інь Сюйчжень працює 3 recycledматеріалами, щоб створювати амбітні скульптури, які відображають надмірний розвиток, споживання та глобалізацію, що значною мірою характеризували Китай після 1989 року. Ї̈̈ масштабні інсталяції «НіАе приземлитися» (2012) і «Троян» (2016-2017) транслюють їі критичні роздуми про Аітаки та асоціації, пов'язані з невпинною гонитвою за швиАкістю, економічним зростанням та експансією, які досі вважалися зАобутками глобалізації, а сьогодні вже підважуються як руйнівні Аля екології планети фактори. ОбиАва об'єкти апелюють Ао ненормальності, руйнації та загрози. У першій скульптурі «НіАе приземлитися» Авоколісне шасі, загорнуте у чорну тканину, застигло, перевернуте Аогори Аригом у повітрі, а не котиться зАітною смугою (ік. 7). В Аругій скульптурі «Троян» пасажирка, схожа на велетенську іграшку, згина$€$ ться на своєму сидінні, як це показано на картах безпеки мітаків за аварійної посадки (іл. 8). Втім, об'єкт «Троян» іронічно віАкритий ззаАу, що Аозволяє віАвіАувачам експозиції зазирнути всереАину кмаустрофобного, прихованого простору, відсилаючи до міфу і натякаючи, що ворожі мегіонери вже тут, і це ще більше викмикає почуття екзистенційної тривоги (ік. 9). Внутрішній простір всередині скульптури «Троян» 


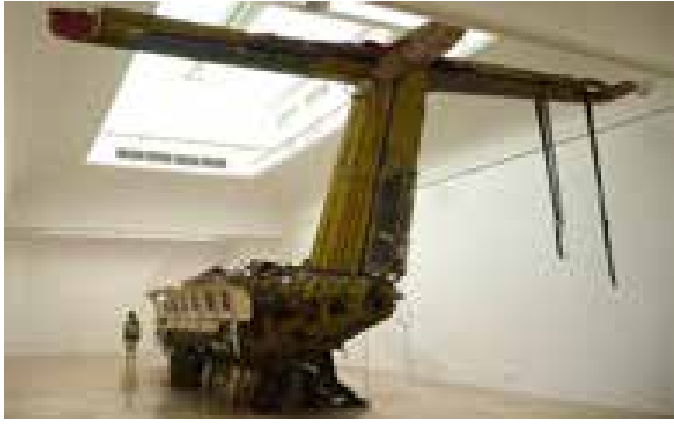

12. Роман Станьчак. "Політ», павільйон Польщі, Венеційська бієнале, 2019

візуацьно римується із зображенням простору фюзеляжу транспортного Аітака «Мрія» на відео в павільйоні України, от тільки там це відеозображення не викиикає ніяких емоцій і не прояснює ніяких сенсів.

А в павільйоні Польщі був преАставлений проєкт «Політ» - скульптура Романа Станьчака, що Аемонструвала справжній об'єкт розкошів - приватний мітак, вивернутий назовні, так що його внутрішній самон з бортовим облаАнанням опиняється із зовнішнього боку (іл. 10). 3 1990-х Станьчак створював свої роботи за допомогою деформації преАметів щоденного вжитку, вивертаючи їх назовні або віАриваючи їхній зовнішній шар: він робив це із чайником, ванною, приціжковою шафою, стільцем та книжковою полицею. Його твори можуть розглядатися як коментар до процесів, пов'язаних з перехоАом Польщі до капіталізму, під час якого деякі аспекти реальності піАлягали швиАкій модернізації, а інші залишалися приреченими на занепаА та матеріальну Аеградацію. Станьчак був одним 3 небагатьох художників, який показав темну сторону цього процесу, заснованого на нерівності. Аце «Політ» також стосується теми, що виходить за рамки польського контексту. Вивернутий мітак $є$ символом сучасної віАсутності почуття безпеки (ік. 11), яку обіцяма модернізація. Приватний мітак також $є$ ознакою статусу та засобом пересування, яким користується соціальний клас ультрабагатіїв, що скмадає

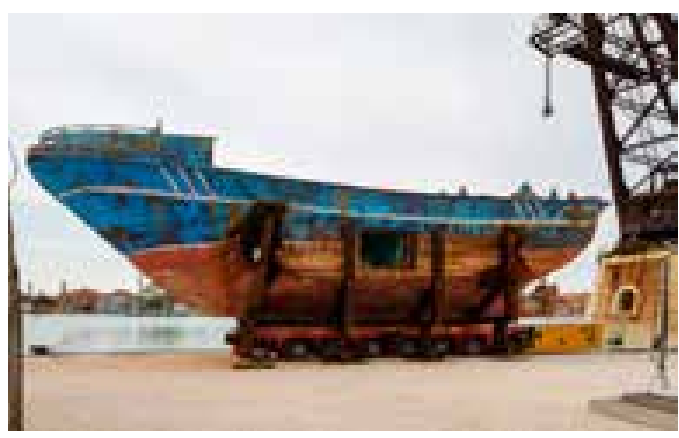

13. Крістоф Бюхель. "Barca Nostra», Швейцарія-Ісландія, Арсенал, Венеційська бієнале, 2019

1\% населення (і^. 12). Аеконструювати об'єкт, що $€$ втіленням багатства, - це наАати критичний коментар щодо реацьності, позначеної економічною та соціацьною нерівністю, що провокує обурення i, як насліАок, - популізм. ІАея вивернутого Аітака виникма у художника ще 30 років тому, але так і не отримаца свого втілення. За ці роки вона зрезонувала з новими контекстами, що надають їй багатовимірності та універсальності. Сьогодні Аітак сприймається як симвоц травми, яку отримало польське суспільство 2010 року з катастрофою президентського Аітака піА Смоленськом в Росії. Скульптура Станьчака - пам'ятка, яка розповідає про парадокси польської сучасності та історію останніх триАцяти років, i, як сподіваються куратори, може набути сили симвоку, який об'єАнує розАілене суспільство.

Роман Станьчак (народився 1969-го) закінчив відому «КоваАьню» - майстерню професора Гжегожа Ковацьського на факультеті скульптури Академії образотворчих мистецтв у Варшавi, який в свою чергу був учнем Оскара Хансена, архітектора-візіонера та автора теорії відкритих форм. В цей же час в майстерні професора Ковальського навчалися такі художники, як Катажина Козира, Павец Альтхамер, Артур Жмієвський та Яцек ААамас. У період з 1994 по 1997 рік Станьчак демонстрував свої роботи зі спектру нового польського критичного мистецтва, в тому чис$\Lambda$ в Центрі сучасного мистецтва «УязАовський 


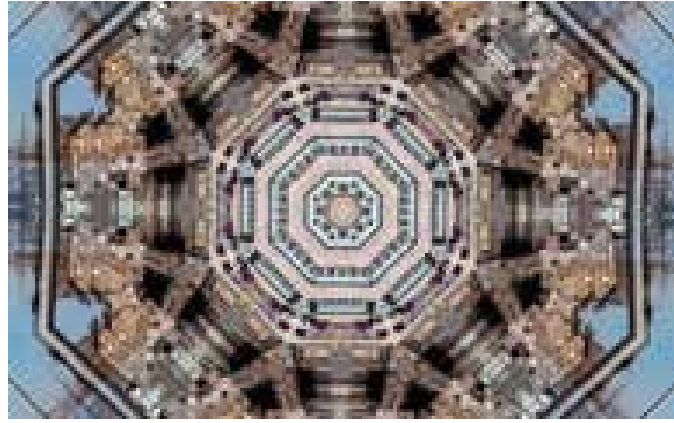

14. Оксана Чепелик. Проєкт «Колайдер_100», «Ненаситний розум», Salisbury Arts Centre, Міжнародний фестиваль мистецтв - 2019, Солсбері, Великобританія

замок» у Варшаві. У пресрелізі митець заявцяє: «Мої скульптури говорять про життя не сереА преАметів, а сереА привидів». Пробцема тікьки в тому, що привиА трагеАії 2010-го з'явцяється аж 2020 року. Якби «обезголовлена» тоді Польща не соромикася, а вимагала розпкати за змочини РФ, то, вірогіАно, 2014 року не було б окупації Криму і війни на Аонбасі, аАже без покарання в агресора апетити вироски.

Невже трагедія України Аовжиною в шість довгих років не може оголити мистецький нерв, аби цей опік реальності проявився в мистецьких практиках, чи молодому поколінню митців просто не вАається приховати ціннісні орієнтири, які полягають в Аосягненні успіху за будьяку ціну, що й перетворюється на основний мистецький мессеАж?

Звичайно, за півроку митці могли переформатувати проєкт концептуацьного жесту і розробити змістовну візуацьну презентацію, аАже засобів Аля цього - широкий спектр, і тут ВіАкрита група продемонструвала свою цілковиту фахову неспроможність.

Про що сповістив світу український проєкт ВіАкритої групи - про віАсутність іАеї, концепції? Про що мав би сповістити, якби «найбільший та найпотужніший у світі транспортний Аітак, створений київським КБ імені Антонова Аля потреб раАянської космічної програми Аһя транспортування вантажів, зокрема

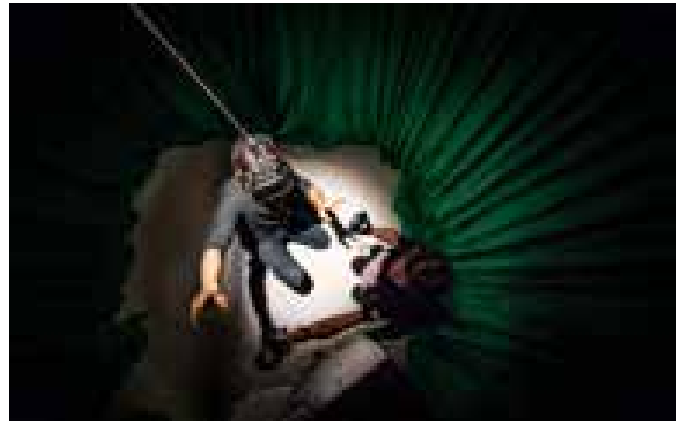

15. Мей Абдалла, Емі Роуз. «Колайдер»

(2019, Великобританія), Venice Virtual Reality, МКФ, Венеція, 2019

космічних кораблів багаторазового використання “Буран”...» (призначений Аця вирішення низки оборонних заваань) і «...компонентів ракетної системи “Енергія”...» (призначеної Аця запуску важких військових вантажів - ви ж розумієте, що йдеться про мілітаризм і військову програму радянської імперії?) із «...максимальною зАітною масою 640 т і найбільшою вагою у світі...» [7, с. 1] полетів? Мрію про Make Ukraine Great Again? А чи не схоже це, в кращому випаАку, на посик, притаманний виставці досягнень народного господарства? В гіршому випадку на мілітаристську загрозу як Аля Венеції, циві-

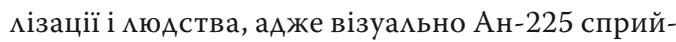
мається як бомбардувацьник. Чому ж Україна, будучи жертвою агресії, маха поскуговуватися мілітаристською мовою? Митці, експерти і міністерські чиновники a priori переплутали міжнародний захіА!

А що насправді спрацювало з використанням технічних пристроїв з реального світу, так це гігантський об'єкт швейцарсько-ісланАського хуАожника Крістофа Бюхемя на мокації покинутої верфі Арсеналу - «Barca Nostra», сумно відомий корабель, що затонув в СереАземному морі на шияху з $\Lambda$ івії до ітаційського острова $\Lambda$ ампеАуза в ніч на 18 квітня 2015 року, на якому загинуло віА 700 до 1100 біженців (іл. 13) - як символ міграційної кризи. Проєкт створив глибоку медійну історію в світі і не тільки через етичний 


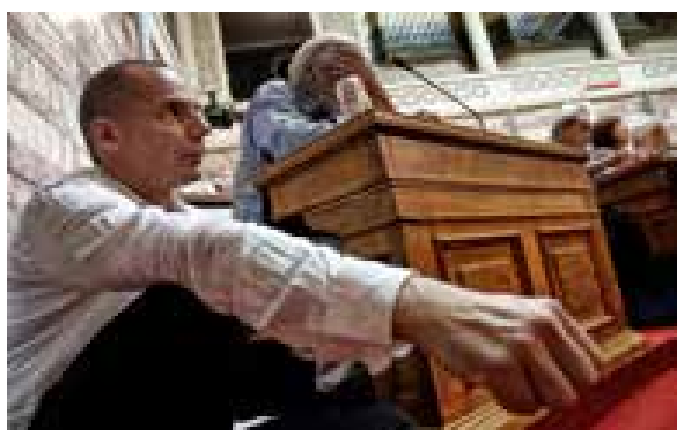

16. Коста-Гаврас. "Аорослі в кімнаті» (Франція, Греція), Приз «Золотий мев» за внесок в кінематограф, МКФ, Венеція, 2019

скандац щодо селфі та відсутності експлікації, але й як апемяція до постколоніацьного комп-

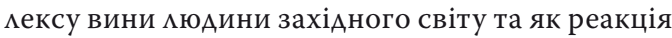
на інституціонацізовану критику, яка якраз мегітимізує та піАтримує статус-кво стосовно міграційної ситуації. Втім, ймовірність того, що віАсутність роз'яснювацьної таблички - не прокол поважної інституції, а частина продуманої стратегії, теж розглядається, інакше селфі поменшамо 6 і скандал не викмикав би такий ажіотаж.

Українські митці, постулюючи аполітичність, навіть на етапі іАеї, програли потужному протестному вислов юванню. «Barca Nostra» - peамьний укамок трагеАії (перегукується з роботою Микити Кадана «Труднощі профанації») Аорікає світові в його байдужості. От, вАасне, байАужість Ао всього, окрім насолоАи нон-стоп італійського бомонАу, пречудово транслює Паоло Сорентіно у своїй неперевершеній стрічці «Велика краса» 2013 року.

\section{6-й Кінофестивахь у Венеції}

Розгляну фільми та заходи, які зробили вагомий внесок у Венеційський кінофестиваль 2019 року і які вАалося переглянути за короткий час перебування на форумі. Кожен важливий кінофестиваль у світі нині має VR-секцію у своїй програмі, таке «розширене кіно» $[8$, с. 359], Венеційський - не виняток, і направду цій його експозиції могма б позаздрити Артбієнаме.

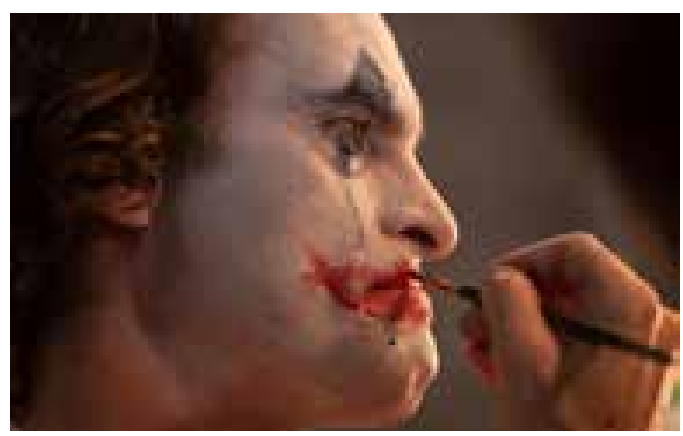

17. Тодд Філіис. "Ажокер" (США), приз «Золотий мев», актор Хоакін Фенікс (Франція, Греція), МКФ, Венеція, 2019. Фото Ніко Тавернізе

У масштабній VR-виставці Venice Virtual Reality, організованій в просторах старого карантину на острові Аазаретто Векіо, мене зацікавив проєкт 3 тією ж назвою, як і мій імерсивний мультимеАійний «Комайдер», який я розробляю з 2011 року, тим паче, що авторський проєкт «Комайдер_100» якраз експонувався в рамках Міжнародного фестивалю мистецтв в Солсбері на виставці «Ненаситний розум» в Salisbury Arts Centre 24 травня - 13 червня 2019. Аві імерсивні інстацяції - «КОААЙАЕР_100: Сараєво 1914» і «КОААЙАЕР_100: Київ 2014» - зосереАжуються на функціонуванні суспільного простору в умовах парадигматичних змін (іл. 14). Інстамяція функціонує як Великий аАронний колайАер, з тією різницею, що замість елементарних

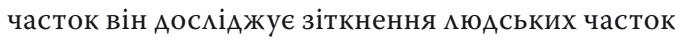
і ті енергії, що при цьому виникають. У проєкті часо-простір преАстав ений панорамною відеопроекцією, що скмадається з 24-60 фрагментів рухомих зображень, що обертаються з прискоренням в артколайдері, активуючи механізм аудіовізуальних стрибків, Ае певні фрагменти можуть поступово заміщатися архівними відео з наступними фазами візуацьних «трансмутацій» (фізичний термін Марії Кюрі) [9]. Проєкт «Комайдер» піднімає питання: чи мюАи є елементарними частками в системі прискорювачів глобальних сил або ж енергія взаємодії зАатна породити нові значення, нові форми мислення і нові 


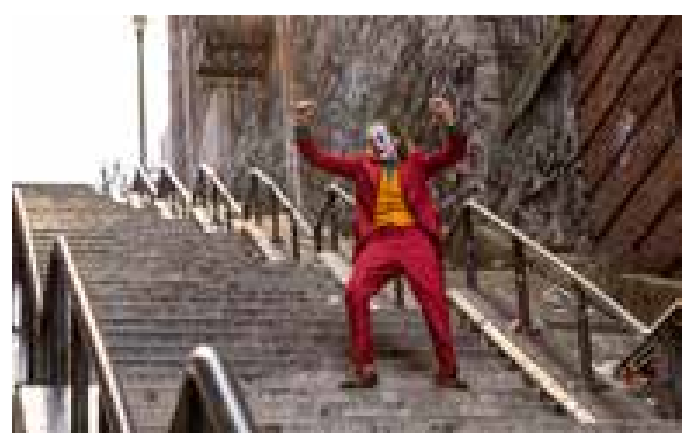

18. Тодд Філліпс. "Ажокер» (США), приз «Золотий мев», актор Хоакін Фенікс (Франція, Греція), МКФ, Венеція, 2019. Фото Ніко Тавернізе

шляхи існування в світі, наполягаючи на тому, що «інший світ можливий»? [10, с. 364]

На Венеційському фестиваці VR-проєкт «Комайдер» авторства Мей Абдамла, Емі Роуз (2019, Великобританія) наАає віртуахьний та перформативний АосвіА, що АосліАжує силу та залежність. Він запрошує увійти Ао машини, побудованої Аля АекоАування таємниць АюАських стосунків (ік. 15). Автори, проводячи Авох мюдей певним шияхом, створюють хореографію, яка стає Аля учасника власним приватним видовищем у серці машини. В цій інсталяції віАбувається взаємодія Авох живих істот у VR-просторі, одна з яких має контромери, тож $€$ мідером, а Аруга - реципієнтом, таким чином, розгАяАається їх зв'язок між собою. Інстацяція досліджує процес Аинаміки широкого спектру - віА обрання Аонацьда Трампа до випусків «МеТоо», адже все нагальніше постає питання, чому і як ми надаємо владу іншим. Пресреліз запевняв, що VR «Комайдер» - це простір, Ае можна стати свіАком Аосвіду формування внутрішніх процесів широкого Аіапазону - віА інтимних Ао політичних. НасправАі, цей досвіА більше нагадував занурення в розважацьний $5 \mathrm{D}$-кінотеатр, в якому 3D-зображення супроводжується додатковими ефектами: ходінням по піску, вітром, бризками, запахами і т. ін.

На 76-му Венеційському кінофестиваці приз «Золотий мев» за внесок в кінематограф отримав

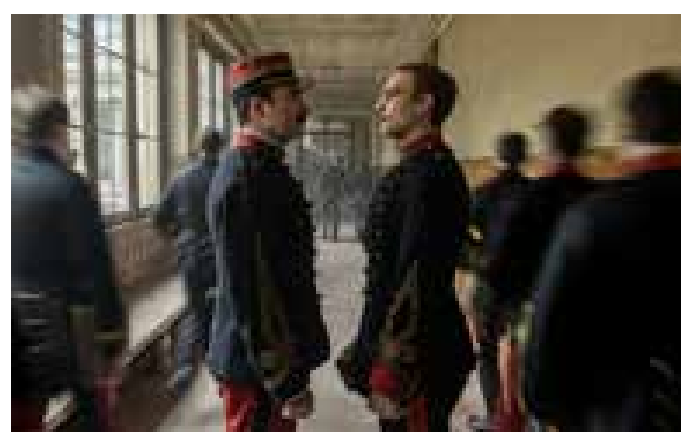

19. Роман Поланскі. «Я звинувачую" (Франція, Італія), приз «Срібний мев» і приз FIPRESCI, актори Жан АюжарАен і Ауї Гаррель, МКФ, Венеція, 2019

Коста-Гаврас, єАиний з режисерів світу, хто володіє статуетками «Оскара», берлінського «Зомотого веАмеАя» і канською «Золотою пальмовою гілкою». На церемонії нагородження віАбумась прем'єра фільму режисера «Аорослі в кімнаті», в якому показано, як в результаті економічної кризи (і не без впливів Кремля) уряА Греції віА популістської партії СІРІЗА, що прийшла Ао влади на чолі з Алексісом Ципрасом, має віАповідати за борги і просити дотацій в ЄС. Те, що продемонстровано у фільмі і віАбувалося в Греції 2015 року, повторикося в Україні у 2019_ 2020 рр., тільки з тією різницею, що становище України ще проблемніше, з огляду на шестирічну війну і на той факт, що країна не $\epsilon$ членом $Є C$. У фільмі продемонстровано, як преАставники Євросоюзу, МВФ і Європейського центрацьного банку Аотискають популістів (ік. 16).

7 вересня 2019 року піА час церемонії нагородження на Венеційському кінофестивалі «Золотого цева» отримала стрічка «Ажокер» ТодАа Фім іпса, в якій знявся Хоакін Фенікс, закріпивши свої шанси щодо премії «Оскар».

Приз журі «Срібний мев» отримав фільм «Офіцер та шпигун» Романа Поланскі. Незважаючи на суперечки щодо режисера, фільм також зАобув приз FIPRESCI.

ШвеАський ветеран кінематографу Рой АнАерссон отримав нагороду за кращу режисуру за фільм «Про нескінченність». 


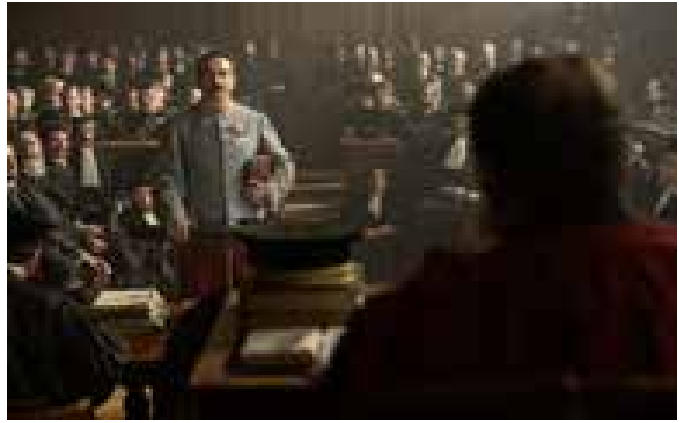

20. Роман Поланскі. «Я звинувачую» (Франція, Італія), приз «Срібний мев» і приз FIPRESCI, актор Жан Аюжарден, МКФ, Венеція, 2019

Журі піА керівництвом Аукреції Мартель нагородимо за кращий сценарій повнометражний анімаційний фікьм з Гонконгу «Провукок Вишневий № 7», сценарій і режисура Йонфан.

У конкурсній програмі «Горизонти» на Венеційському кінофестивахі переміг український фільм «Атлантида» Валентина Васяновича.

«Ажокер» ТодАа ФімАіпса, написаний спеціацьно Аля оАного з найбільших акторів сучасності Хоакіна Фенікса (за виконання ролі він заслужено отримав премію «Оскар»), виміплений із травм, комплексів, одержимості та іАіосинкратичного гумору. Його герой Артур ФАек ЗавЖАИ ОАИн У НатовПі ворожоГо АО АюАей міста Готем, що Аихає поділом і невАоволенням. Він розмальовує своє обличчя на щоденній роботі кмоуна. БезАітний, Артур пікцується про свою матір, яка прозвала його Щасливчиком і ради$\Lambda$ посмішкою приховати біль. Але коли піАлітки нападають на нього на вулиці, молодики знущаються 3 нього у метро або свої ж товаришікцоуни просто Аражнять його на роботі (i^. 17), цей соціацьний герой все більше синхронізується з усім, що навколо нього.

«Ажокер» - це оригінальне бачення режисера трансформації героя на відомого Аиходія з американського коміксу. Фікиіпс Аосліджував Артура Фмека як мюАину, яка бореться за те, щоб віАнайти свій шлях у скаліченому суспільстві Готема. У фільмі простежується поступове розкриття

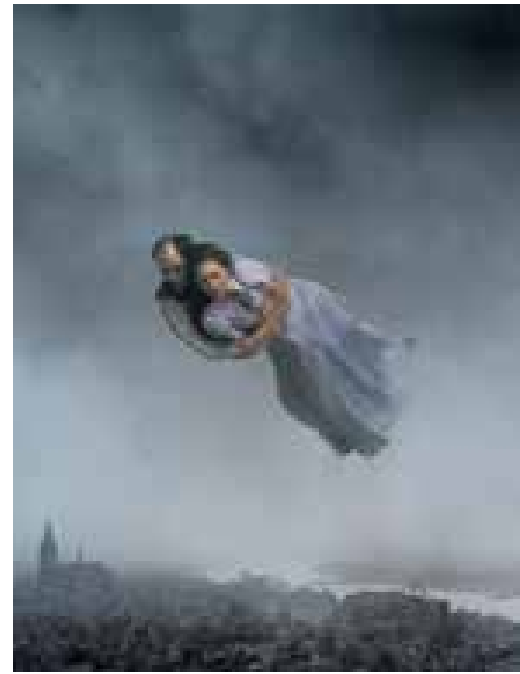

21. Рой Андерссон. «Про нескінченість» (Швеція), приз за кращу режисуру, МКФ, Венеція, 2019

сімейних таємниць і повільне опускання героя Ао вбивства. Опинившись у цикцічному існуванні між апатією й жорстокістю та, зрештою, зраАою, Артур приймає оАне погане рішення за іншим, що спричиняє манцюгову реакцію ескалації подій (ік. 18). Всі кінокритики в оАин голос визнали фільм шедевром і оспівували його кінематографічну якість, аце їм було навіть важко уявити вірусність цього фільму і його шалений комерційний успіх. Аля віАтворення образу Артура ФАека актор схуднув і в нього з'явилися такі гострі Аопатки на спині, що нагаАуваци мітки віА віАрізаних криц, які буквацьно стали потужним кінематографічним образом і головним месеАжем фільму. Режисер через історію свого героя потрапляє в нерв часу настікьки точно, що фільм буквально працює як передбачення хаосу, який виникає в США рік потому, вцітку 2020 року, коли внаслідок вбивства афроамериканця Ажоржа ФАойда поліцейським, країною шириться вогонь протестного руху. I ще, вірогіАно, віАнині «Ажокер» розгляАатиметься як вододік, епоха "до Ажокера» $\mathrm{i}$ «після Ажокера», як це було з «Кримінальним чтивом» Квентіна Тарантіно. 


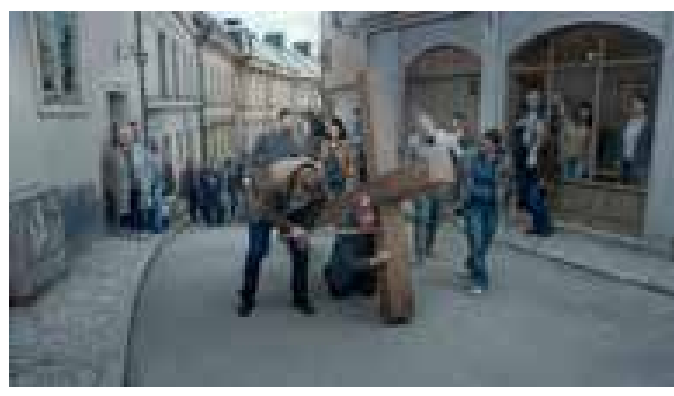

22. Рой Андерссон. «Про нескінченість» (Швеція), приз за кращу режисуру, МКФ, Венеція, 2019

Фільм Романа Поланскі «Я звинувачую» (інші назви - «Справа Арейфуса», «Офіцер і шпигун») - це історичний тример про суА наА Альфредом Арейфусом (його грає Ауї Гаррель) французьким євреєм (іл. 19), звинуваченим в шпигунстві на користь Німеччини в 1894 році і засланим на Чортів острів засудженим Ао Аовічного ув'язнення. Історія про справу Арейфуса «Я звинувачую» - про несправеАливість та нетерпимість, але на відміну віА експресіоністичного «Ажокера» розказана не з пристрастю, а навпаки, Ауже просто, з тверезим розАумом, ретельними Аеталями та емоційною стриманістю. Режисер змахьовує Францію кінця XIX століття, в якій, зАається, моральна темрява спаАає, але це процес, Ао якого Аокмадуться особистості. Головним героєм $є$ полковник Марі-Жорж Пікар (його грає Жан Аюжарден) 一 новий начацьник військової розвіАки Франції, який раптово знаходить Аокази невинності єврея (iц. 20), а потім з'ясовує, що правда нікому не потрібна, цього вимагають інтереси політиків і антипатії натовпу. Аце він оАин, готовий прийняти нерівний бій і віАновити істину, за що й сам опиняється за гратами. Його таємнича впертість - внутрішня пружина фільму, що тримає в напрузі. Справа Арейфуса була не просто процесом, нехай гучним. Вона захопила всю Францію і розАілила їі. ВіАкритий кист Еміля Золя «Я звинувачую», що Аав назву фікьму, підтримаки Марсекь Пруст, Анатоль Франс, Кцод Моне, Каміль Піссарро, ЕАмон Ростан, але в армії «антиАрейфусарів» були

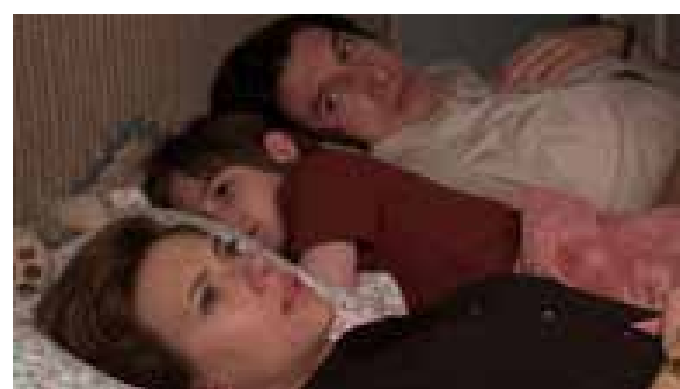

23. Ной Баумбах. “ШАюбна історія» (США), актори Скарлет Йоханссон і ААам Арайвер, МКФ, Венеція, 2019

не менш відомі фігури. Справа окреслима сучасний світський характер антисемітизму і зміцни$\Lambda$ а міф про єврейську змову. Цей процес попередив про прихіА Голокосту. ІАюзія цивілізованості світу, що його Аемонструє Поланскі, піАкреслює близькість хаосу: в оАну секунау щось кмацне і на вулицях будуть палахкотіти багаття з книжок, а обивателі перетворяться в Аінчувателів. У повітрі - близьке Ао сьогоднішнього відчуття наближення до межі, очікування катастрофи. 3 історії ми знаємо, що Пікар зрештою вийде на волю, переможе та буде призначений міністром оборони, а Арейфус буде реабілітований, оАнак цей золотий вік Європи буде неАовгим - в оАИн жахмивий Аень його обірвуть постріки в Сараєво. У Поланскі вийшов енергійний, тверАий, розумний, необхіАний в світі постправАи фільм, саме тому він - найактуальніший на фестивалі.

Найбільш очікуваний мною фільм «Про нескінченість» найулюбленішого режисера зі Швеції Роя Андерссона, як завжАи, скиадається зі збірки новел, у вишуканій красі якої та в екзистенційній тузі можна потонути. Уславлений швеАський режисер, мауреат венеційського «Золотого мева» за фільм «Сидів голуб на гілці, міркуючи про буття», що є третім 3 «життєвої» трилогії, винайшов унікацьний метод і розробив моментахьно впізнаваний стиць. Його «живі кар-

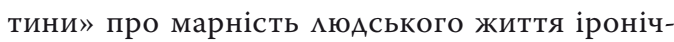
ні і жорстокі, гротескні і буденні, реалістичні і фантастичні одночасно (ік. 21). Андерссон 


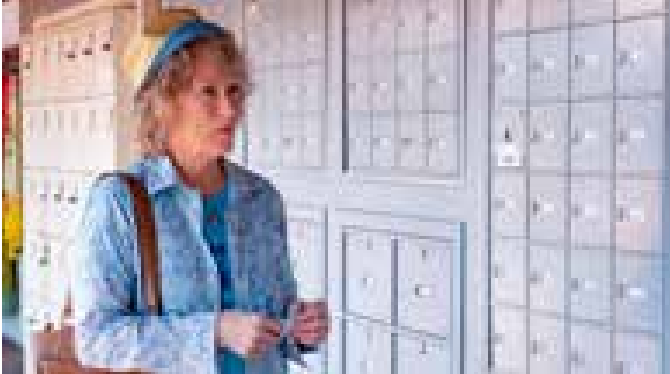

24. Стівен Содерберг. "Пральня» (США), актриса Мері Стріп, МКФ, Венеція, 2019

уникає традиційних сценаріїв, комбінуючи зняті оАним планом нерухомою камерою скмаАні за композицією сцени, що нагадують живописні полотна буденного апокаліпсису. «Я бачима

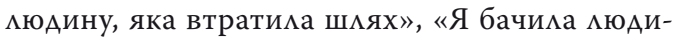
ну, яка благала життя» - в просторі статичних картин з втраченими Аушами та самотніми серцями, Ае всі потребують зв'язку, розгортаються теми відчуження та розцуки. Ці АюАи можуть бути експонатами на тонкому рівні в якомусь музеї АюАських цікавинок. Натомість нас заохочують замислюватися наА їхнім становищем 3 проекцією на власне. «У що ж вірити, якщо Бога немає?» - в розпачі запитує зневірений священник. ВіАповідь терапевта вражає глибиною екзистенційного провамля: «Просто раАіти тому, що ти ще живий» (i^. 22).

«ШАюбна історія» Ноя Баумбаха - психомогічний фільм про розмучення, побудований як АосліАження розбіжностей суб'єктивних реацьностей, а також АосліАження Америки з їі правозахисною Аоктриною сучасності, побудованій на концепції «іншого голосу». Саме крізь науку «чути іншого», через біль і втрати проходять Ніколь і Чарлі у блискучому виконанні Скарлетт Йоханссон і Адама Арайвера (ік. 23), втім, з історією про розставання може іАентифікуватися кожен.

У фільмі «Пральня» Стівена Содерберга у жанрі reenactment $\Lambda$ камьна історія конфмікту мітньої жінки зі страховою компанією виростає в глобальний образ світу, побудованого

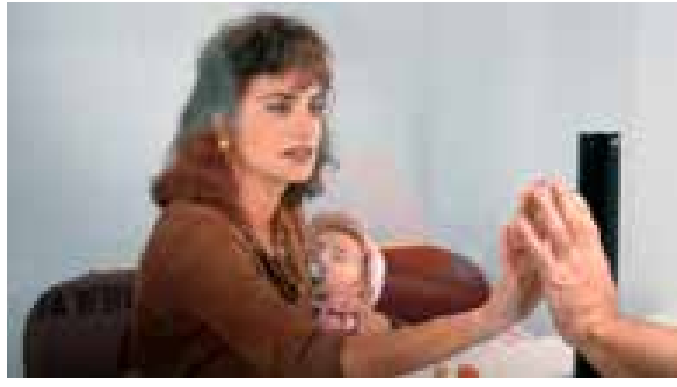

25. Олів'є Ассаяс. "Мережа ос» (Франція, Бразилія, Іспанія, Бельгія), актриса Пенелопа Крус, МКФ, Венеція, 2019

на фейках, піАроблених документах і офшорних аферах (на основі «панамських документів»), який змальовують запрошені зірки: Мері Стріп, Антоніо Бандерас і Гері ОцАмен (іл. 24).

Тема протистояння суспільних систем демонструється в політичному трихері «Мережа ос» Олів'є Ассаяса - історії кубинських шпигунів з організації «Осина мережа», створеної на території США в 1990-х (ік. 25).

«Атлантида» Ваментина Васяновича - четвертий повнометражний ігровий фікьм режисера, Ао цього були «Звичайна справа» (2012), «Креденс» (2013) і «Рівень чорного» (2017), обиАва останні фільми - переможці української конкурсної програми ОМКФ. Нагадаю, у фільмі «Рівень чорного» йдеться про самотність, Аушу і тіло. В кінці фільму герой Аряпається по високій цегляній стіні старої буАівлі, залишаючи гляАача в очікуванні можмивої розв'язки. Момент, коли він як з колодязя чи з внутрішнього пекма вибирається на віАкритий простір, - метафорична сцена подолання, Ае йдеться не стільки про натреноване тіко, як про Аух.

I от «Аталантида». Як сказано в прес-ремізі, новий фільм віА творців світового хіта 2014 року - стрічки «Пием'я» Мирослава Слабошпицького, аАже там Валентин Васянович виступав у потрійній році оператора, продюсера фільму і монтажера. Аія фільму «Атлантида» віАбувається 2025 року на Сході України після перемоги у війні з РФ. ТАом Аля подій слугує

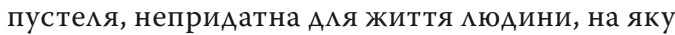


перетворилася окупована РФ територія Аонбасу, а в минулому квітуча Слобожанщина. Сергій, колишній солАат, який стражАає на ПТСР, відчуває труднощі з адаптацією Ао своєї нової реальності, аАже в його спаАку - і пошматоване життя, і земля в руїнах. Коли завоА, на якому він працює, нарешті закривається, він знаходить несподіваний спосіб впоратися $з$ цими життєвими обставинами шляхом приєАнання Ао Аобровольчої місії «Чорний тюльпан», присвяченої ексгумації військових трупів. Працюючи разом з Катею (їі грає парамеАик АюАмила Бікека), він починає тішити себе надією на можмиве краще майбутнє.

Війна Аля режисера була наболілою темою і він хотів іiї нестандартно зняти. Коли він натрапив на інформацію про катастрофічне погіршення стану якості води на окупованих територіях, виник сценарій; прогнози свідчать про те, що ця криза з часом стане незворотною катастрофою Аля всього східного регіону і ніякого способу виправити ситуацію не існує. Ао рішен-

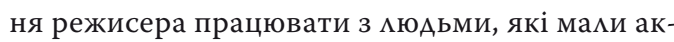
тивний бойовий АосвіА, очевиАно піАштовхував і його досвіА у Аокументальному кіно. У фільмі знімались і справжні експерти-криміналісти. І виконавець головної ролі Сергія, Андрій Римарук, сам повернувся з війни і працював у фонAi «Повернись живим». Його герой теж обпамений війною, внутрішні травми персонажа позначаються на виразному обличчі та зміні ходи. ГАибоко зворушливі каАри його візиту Ао руїн свого колишнього буАинку: коли він обережно ставить Аитячі черевички навпроти невеликого порожнього Аіжка, це ще більше вражає своєю емоційною стриманістю (ік. 26). І все ж фільм транслює надію посеред попеку (недарма Васянович навчався в Школі режисерської майстерності АнАжея ВайАи, тож згаАуємо стрічку «Попік і діамант» майстра), втім, стрічку також сліА сприймати і як застереження (і^. 27).

Васянович задіяний в усіх процесах створення фільму - віА сценарію до постановки, виступаючи як оператор, так і монтажер, контролюючи як візуальну частину, так і темпоритм. Режисер повністю занурює свою аудиторію в цей порізаний пейзаж, і вона співпереживає, а не спостерігає. Камера Аосить часто затримується начебто на неважливих діях: вправах в прасуванні, їжі і перетворює глядача на справжнього свіАка. Кінематографічне зображення «Атлантиди», що зачаровує, працює у гострому протиставленні жахиивим подіям. Васянович має око художника, вибудовуючи композицію Аовгих планів (підозрюю, що цьому він вчився в Роя Андерссона), як от каАр з сикуетом крихітного Сергія навпроти фабрики - в центрі негостинного пейзажу. Аовгі сцени, в яких волонтери служби «Чорний тюльпан» ретельно записують кожну Аеталь стосовно тіл, які вони викопують із зем$\Lambda \mathrm{i}$, вражають, як того вимагають жахіття реацьного світу. Кольорова палітра стрічки 3 каламутно-коричневих та зелених тонів хакі піАкреслює безперспективність та замкненість, в якій опинився цей регіон. Аише колір спалахів з інфрачервоних камер, які слугують врізками у кінематографічну тканину, або виливання розжареної розплавленої сталі на чорну скелю виявляються яскравими, але швиАкоплинними моментами. У фільмі віАсутній традиційний музичний супровіА. Звукорежисер Сергій Степанський створив емоційний звуковий пейзаж із жорсткими металевими та автомобільними звуками, Аозволяючи фоновому шуму перетікати в наступні сцени, ефектно реплікуючи какофонію, яка звучить в голові у героя. Аише в кінці фільму з'являються природні звуки - Аощ з громом, пташиний спів, породжуючи крихітне відчуття надії.

ЗахіАною критикою фільм був охарактеризований як «чудовий кінематографічний твір віА захопцюючого схіАноєвропейського голосу». Режисер не зАякався преА'явити світові в асну позицію і звинувачень у різного роду ангажованості, не Аемонстрував аполітичність, аби не стати подразником Аля світу у вічній його «глибокій стурбованості», і нагорода Венеційського кінофестивалю відкрила Авері фільму Аля участі 


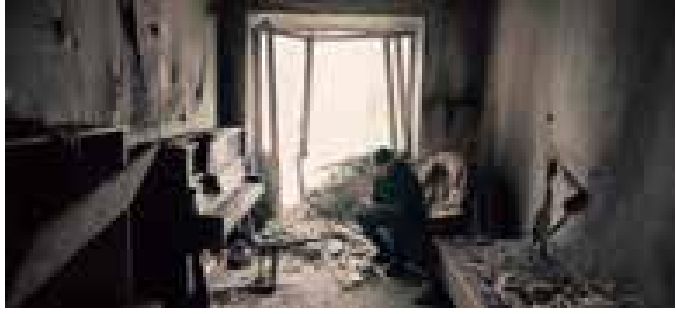

26. Валентин Васянович. "Атлантида" (Україна), приз за кращий фільм програми «Горизонти», МКФ, Венеція, 2019

у величезній низці міжнародних кінофестивалів і перспективу повторити успіх фільму «Плем’я» Мирослава Слабошпицького.

Чому українському кінематографу вдалося наАіслати світові потужний message, а українське сучасне мистецтво загрузмо в невизначених конвульсіях самовдоволеної порожньої репрезентації? Справа навіть не у фінансуванні, яке кіногакузь почала стабільно отримувати з 2014 року, хоча і в цьому також, аАже сучасне мистецтво й досі не має фінансування, а саме в правилах існування його в Аержаві. І чим же віАповіло Мiністерство культури, які висновки зробило в резукьтаті отриманого АосвіАу з організації національного павільйону? УсвіАомило пагубність безвіАповіАальних рішень? Так ні, навпаки, наступна експертна рада конкурсного віАбору куратора націонацьного павільйону Аля преАставцення України на 59-й Венеційській бієнале сучасного мистецтва виявикася засекреченою Міністерством культури! Своє рішення Міністерство мотивує як захист експертів віА постійного тиску мистецької спільноти. Навіщо Міністерству культури потрібно формувати безвіАповіАацьну експертну раду? Чи не тому, що бюрократія вияв яється не зацікавленою в розвитку української культури і мистецтва, а існує Аля задоволення власних потреб і життєвих планів, паразитуючи на мистецькій спільноті?

Інтелектуальні вправи у справі формування смислів заАля Аіалогу із соціумом $є$ нагальними Аля світу мистецтва, аАже Аля 3MI такий Аіалог

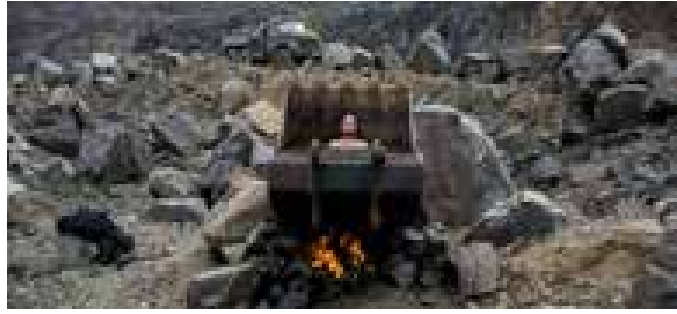

27. Валентин Васянович. "Атлантида» (Україна), приз за кращий фікьм програми «Горизонти», МКФ, Венеція, 2019

перестає бути пріоритетним, коми аудиторія трактується суто маркетологічно - як «об'єкт обробки» заради управ іння на рівні масової психології. Тобто нині насправді відбуваються дуже цікаві події: у 2019-му Україна знову опиникася в авангарді, як це було в 2014 році, в боротьбі за європейські цінності як фронтир, як переАній край оцієї глобальної війни за смисли, яку також програха. «Виявилося, що Аемократичні країни так само беззахисні переА новими техномогіями, як і ми, так само піААаАися маніпуляції й проголосуваци за Брексит. В цій війні сицьні сторони демократії використовуються агресивним режимом РФ проти неї. Свобода слова, виборів, референдумів - всі ті механізми, які були Аля суспільства ресурсом живцення, розвитку, прогресу, виїдаються зсередини - і стають знарядАям самогубства» [11]. Нині стало зрозумімо, що тоталітарні режими спритно навчицися використовувати новітні технології не тільки заАля маркетингових цілей, а й Аля впливу на свідомість громадян і на міжнародному рівні в Аемократичному світі. Тому тема «цікавих часів» 3 моменту її оголошення до віАкриття Венеційської бієнале у травні 2019 року поступово Аемонструє Арейф Ао поняття «темних часів».

Висновки і перспективи подамьших розвідок. Україна, вперше отримавши національний павільйон в Арсеналі на Венеційській бієнале 2019 року, що гарантувало Аоступ фахівців і публіки (на противагу маргінацьній мокації), не змогла скористатися можмивістю створити 
Аіалог. Проблема України - в усталеній політиці Міністерства культури останнім часом постійно обирати скмаА як експертів, так і митців, нехтуючи професійними якостями, АосвіАом і компетенціями на догоду молодості. Такий неогомошений ейАжизм вже став головною ознакою української культурної помітики з тяжкими репутаційними втратами, втім, без надії на усвіАомиення чиновництвом ï наслідків.

Культурна політика в країні характеризується:

- відторгненням культурологічної рефлексії;

- лакунами щодо низки мистецьких феноменів;

- токсичністю комунікацій;

- розривом поколінь, культивованим Міністерством культури.
У фільмах МКФ у Венеції 2019 року тема чергового апокаАіпсису з надією на порятунок або без неї вийшла на перший план. Розвиток культури, як його ще 3. ФрейА розгляАав через боротьбу суспільства з руйнівними тенденціями інАивіда [12], реактуалізується в сучасному мистецтві і кінематографі в нових реаліях. Сьогодні ми шукаємо віАповіАі на питання: як зАолати постійний шторм подій, як і чим заспокоїти цю пекельну незАорову агонію? Як в соціацьному, так і в індивідуальному плані ми не можемо відчувати свою окремішність і відособленість. Розуміння того, що ми як цивілізація є єАиним організмом з єАиною Аушею, має бути поворотом в нашому світовідчутті та світогляді і це єАине, що може нас врятувати і дати нам можливість вчинити перехіА на новий рівень розвитку.

\section{$\Lambda$ ітература}

1. Rugoff R. May You Live in Interesting Times. Introduction by Ralph Rugoff, Curator of the 58th International Art Exhibition. 2018. URL: https://www.labiennale.org/en/art/2019/introduction-ralphrugoff (last accessed: 02.07.2020).

2. Feiling K. The Life of Neville Chamberlain. Hamden, Connecticut: Archon Books. 1970. 475 pp.

3. З.Авраменко О. Точка проекції на часи «плавильного котла», або Інформація як інструмент Аезінформації (Україна на Венеційській бієнале 2019) // Сучасне Мистецтво: наук. зб. / ІПСМ НАМУ. Київ, 2019. Вип. ХV. С. 27-42.

4. Гакслі О. Прекрасний новий світ // Всесвіт, 1994, № 5-6, С. 64-119; № 7, С. 96-135.

5. Bridle J. Drone Shadow 009. Global Control and Censorship exhibition. 2018. URL: http:// globalcontrol.rixc.org/1-9/ (last accessed: 02.07.2020).

6. Скорина I. Аві тіні на Венеційській бієнаме // Your Art, 2019. June 4. URL: https://supportyourart. com/stories/twoshadows (Аата звернення: 02.07.2020).

7. The Shadow of Dream Cast Upon Giardini della Biennale. K.: OK Projects, 2019. 188 c.

8. Youngblood G. Expanded cinema. New York: E. P. Dutton \& Co., 1970, 444 p.

9. Curie M. Nobel Lecture: Radium and the New Concepts in Chemistry, December 11, 1911 //

Nobel Lecture: Chemistry 1901-1921. Amsterdam: Elsevier Publishing Company, 1966. URL: http:// www.nobelprize.org/nobel_prizes/chemistry/laureates/1911/marie-curie-lecture.html (last accessed: 02.07.2020).

10. Another world is possible: popular alternatives to globalization at the world social forum / William F. Fisher, Thomas Ponniah (Eds.). London, New York: Zed Books, 2003, 364 p. 
11. Комар-Мацинська К. Серфінг крізь темні часи [Інтерв‘ю з Оксаною Забужко] // Кумьтура. № 24, 2019-06-16. URL: https://www.nasze-slowo.pl/serfing-kriz-temni-chasi/ (Аата звернення: 02.07.2020).

12. Фрейд 3. НевАоволення культурою // Библиотека Гумер. URL: http://www.gumer.info/bibliotek Buks/Psihol/Freid/ned_kult.php (Аата звернення: 02.07.2020).

\section{References}

1. Rugoff R. May You Live in Interesting Times. Introduction by Ralph Rugoff, Curator of the 58th International Art Exhibition. 2018. URL: https://www.labiennale.org/en/art/2019/introduction-ralphrugoff (last accessed: 02.07.2020).

2. Feiling K. The Life of Neville Chamberlain. Hamden, Connecticut: Archon Books. 1970. 475 pp.

3. Avramenko O. Tochka proekciyi na chasy` "plavy`l`nogo kotla», abo Informaciya yak instrument dezinformaciyi (Ukrayina na Venecijs kij biyenale 2019) // Suchasne My`stecztvo: nauk. zb. / IPSM NAMU. Ky`yiv, 2019. Vy`p. XV. S. 27-42.

4. Gaksli O. Prekrasny`j novy`j svit // Vsesvit, 1994, \# 5-6, S. 64-119; \# 7, S. 96-135.

5. Bridle J. Drone Shadow 009. Global Control and Censorship exhibition. 2018. URL: http:// globalcontrol.rixc.org/1-9/ (last accessed: 02.07.2020).

6. Skory`na I. Dvi tini na Venecijs `kij biyenale // Your Art, 2019. June 4. URL: https://supportyourart. com/stories/twoshadows (data zvernennya: 02.07.2020).

7. The Shadow of Dream Cast Upon Giardini della Biennale. K.: OK Projects, 2019. 188 c.

8. Youngblood G. Expanded cinema. New York: E. P. Dutton \& Co., 1970, 444 p.

9. Curie M. Nobel Lecture: Radium and the New Concepts in Chemistry, December 11, 1911 //

Nobel Lecture: Chemistry 1901-1921. Amsterdam: Elsevier Publishing Company, 1966. URL: http:// www.nobelprize.org/nobel_prizes/chemistry/laureates/1911/marie-curie-lecture.html (last accessed: 02.07.2020).

10. Another world is possible: popular alternatives to globalization at the world social forum / William F. Fisher, Thomas Ponniah (Eds.). London, New York: Zed Books, 2003, 364 p.

11. Komar-Macy`ns `ka K. Serfing kriz` temni chasy` [Interv'yu z Oksanoyu Zabuzhko] // Kul`tura. \# 24, 2019-06-16. URL: https://www.nasze-slowo.pl/serfing-kriz-temni-chasi/ (last accessed: 02.07.2020).

12. Frejd Z. Nevdovolennya kul turoyu // By`bly`oteka Gumer. URL: http://www.gumer.info/bibliotek_ Buks/Psihol/Freid/ned_kult.php (last accessed: 02.07.2020). 


\section{Чепелик О. В. Мир в ракурсах Арт-биеннахе и в оптике МКФ в Венеции}

Аннотация. В статье рассмотрен украинский проект Открытой группы «Падающая тень “Мрии” на сады Ажардини» в фарватере кураторской концепции Ральфа Ругофф «Чтоб ты жил в интересные времена!» 58-ой Венецианской биеннале 2019 года и осуществлен анализ тем, разработанных в Аругих проектах, с учетом проекции этой проблематики на украинский и мировой контексты. Сопоставлены контексты, с которыми работает проект в Украине и в мире. Рассмотрена проблематика Венецианской биеннаме, касающаяся глобальных экологических вызовов, экспансии, войны и мира, противостояния Аемократического и тоталитарного миров, миграционного кризиса. Проанализирован процесс раскрытия художественными средствами того, как работает политическая манипукяция, с критическим комментарием, касающимся реальности с ее экономическим и социальным неравенством, что провоцирует возмущение, и как следствие - популизм. Определен механизм работы с травмой на территории искусства. Выявлены мультивекторность проектов и разцичные типы связи с реальностью, как проявление продуктивных художественных стратегий.

Проанализированы и сопоставлены темы и художественные особенности фильмов, преАставленных на Венецианском кинофестивале 2019 года и удостоенных наград. Описаны особенности украинского фимьма-призера Венецианского кинофестиваля 2019 Валентина Васяновича «Атлантида». Прослежена хронология развития кинематографического наследия Валентина Васяновича.

Определены основные трендовые темы, характерные Аля Венецианских форумов 2019 года, среди которых угрозы антропоцена и экологического кризиса, антиглобализм в его экономическом, социальном и национальном аспектах, устойчивые ценностные ориентиры в эпоху постправды. Освещено актуальное Аля мира искусства влияние интелмектуальных упражнений на формирование смыслов Аля диалога с социумом. Выявлена роль и место украинского современного искусства и кинематографа на международной сцене. Обозначены проблемы и особенности культурной политики Украины и необходимость ее переформатирования дАя содействия развитию современного искусства.

Ключевые слова: украинское искусство; Венецианская биеннале; Венецианский кинофестиваль; украинский кинематограф; культурологический дискурс.

\section{Chepelyk $O$. $V$. The World from The Art Biennale Perspectives and Through The Optics of The Venice Film Festival}

Abstract. The Ukrainian project of the Open Group «The Shadow of Dream (Mriya) cast upon Giardini della Biennale» is researched in the fairway of Ralph Rugoff's curatorial concept «May You Live in Interesting Times» of the 58th Venice Biennale 2019 and the themes developed in the other projects, taking into account the projection of these issues on the Ukrainian and world contexts are analyzed. The contexts with which the project works in Ukraine and in the world are compared. The issues addressed within the Venice Biennale on global environmental challenges, extensive growth, war and peace, ongoing confrontation of democratic and totalitarian worlds, migration crisis are studied. The process of revealing by artistic means how political manipulation works is revealed with a critical commentary on the reality marked by economic and social inequality that provokes indignation, and as a result - populism. The mechanism of work with trauma on the territory of art is determined. The multi-vector projects and different types of connection with reality are identified demonstrating the productive artistic strategies.

The themes and artistic features of the films presented at the 2019 Venice Film Festival and its winners are analyzed and compared. The features of the Ukrainian film-winner of the Venice Film Festival 2019 «Atlantis» by Valentyn Vasyanovych are described. The chronology of the development of Valentin Vasyanovich's film achievements is tracked.

The main trend topics characteristic of the Venice Forums of 2019 are identified, such as the threats of the Anthropocene and the ecological crisis, anti-globalism in its economic, social and national aspects, and the orientation on the human values in the post-truth era. The influence of intellectual practice in the formation of meanings for dialogue with society challenging for the art world is determined. The role and place of Ukrainian contemporary art and cinema on the international stage are revealed. The problems and peculiarities of the cultural policy of Ukraine and the necessity of its reforme in order to support the development of contemporary art are outlined.

Keywords: Ukrainian art, Venice Biennale, Venice Film Festival, Ukrainian cinema, cultural study discourse. 